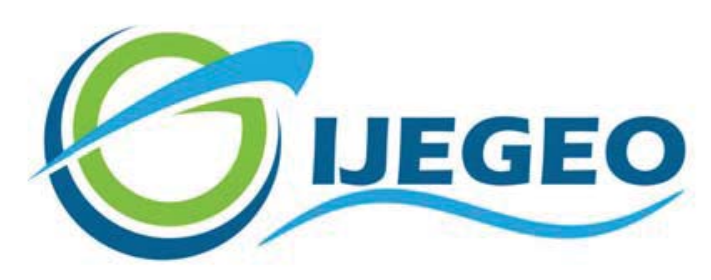

International Journal of Environment and Geoinformatics (IJEGEO) is an international, multidisciplinary, peer reviewed, open access journal.

\title{
The Character of Soil Temperature Regime over Turkey
}

\section{İlyas Sadık TEKKANAT, Beyhan ÖZTÜRK}

\author{
Chief in Editor \\ Prof. Dr. Cem Gazioğlu \\ Co-Editors Prof. Dr. Dursun Zafer Şeker, Prof. Dr. Şinasi Kaya, \\ Prof. Dr. Ayşegül Tanık and Assist. Prof. Dr. Volkan Demir
}

Editorial Committee (June 2022)

Assoc. Prof. Dr. Abdullah Aksu (TR), Assoc. Prof. Dr. Uğur Algancı (TR), Assoc. Prof. Dr. Aslı Aslan (US), Prof. Dr. Levent Bat (TR), Prof. Dr. Paul Bates (UK), İrşad Bayırhan (TR), Prof. Dr. Bülent

Bayram (TR), Prof. Dr. Luis M. Botana (ES), Prof. Dr. Nuray Çağlar (TR), Prof. Dr. Sukanta Dash (IN), Dr. Soofia T. Elias (UK), Prof. Dr. A. Evren Erginal (TR), Assoc. Prof. Dr. Cüneyt Erenoğlu (TR), Dr. Dieter Fritsch (DE), Prof. Dr. Ç; Prof. Dr. Manik Kalubarme (IN), Dr. Hakan Kaya (TR), Assist. Prof. Dr. Serkan Kükrer (TR), Assoc. Prof. Dr. Maged Marghany (MY); Prof. Dr. Micheal Meadows (ZA), Prof. Dr. Nebiye Musaoğlu (TR), Prof. Dr. Masafumi Nakagawa (JP), Prof. Dr. Hasan Özdemir (TR), Prof. Dr. Chyssy Potsiou (GR), Prof. Dr. Erol Sarı (TR), Prof. Dr. Maria Paradiso (IT), Prof. Dr. Petros Patias (GR), Prof. Dr. Elif Sertel (TR), Prof. Dr. Nüket Sivri (TR), Prof. Dr. Füsun Balık Şanlı (TR), Dr. Duygu Ülker (TR), Prof. Dr. Seyfettin Tsaş (TR), Assoc. Prof. Dr. Ömer Suat Taşkın (TR), Assist. Prof. Dr. Tuba Ünsal (TR), Assist. Prof. Dr. Sibel Zeki (TR) 


\title{
Research Article
}

\section{The Character of Soil Temperature Regime over Turkey}

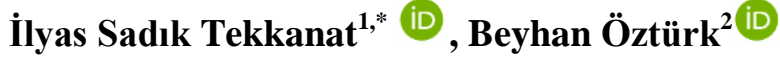 \\ ${ }^{1}$ Geography Ph.D. Program, School of Graduate Studies, Çanakkale Onsekiz Mart University, Çanakkale, Turkey \\ ${ }^{2}$ Department of Geography, Faculty of Arts and Sciences, Çanakkale Onsekiz Mart University, Çanakkale, Turkey
}

* Corresponding author: İlyas Sadık Tekkanat

Received 21.08.2021

E-mail: ilyastekkanat@mail.com

How to cite: Tekkanat and Öztürk, B. (2022). The Character of Soil Temperature Regime over Turkey. International Journal of Environment and Geoinformatics (IJEGEO), 9(2):018-026. doi. 10.30897/ijegeo.985732

\begin{abstract}
This paper presents the spatial and temporal characteristics of Turkish soil temperature regimes. Basic data consists of the monthly soil temperature averages from 153 stations at depths of 5, 10, 20, 50 and $100 \mathrm{~cm}$ for 44 years (1975-2018) record length. The soil temperature regime of Turkey has been analyzed based on both classical climatic regime approach (monthly average soil temperature change) and Soil Taxonomy. As expected, The annual course of soil temperatures differs between the coastal and inland areas of Turkey and in the western and eastern half. Latitude and continentally shapes the soil temperature regime in the eastern half of Turkey while elevation shapes the soil temperature regime in the western half of Turkey. The frost is seen in the eastern half of Turkey in January and February, except for coastal areas. Moreover, the frost period goes up to 4 months (November-February) in northeastern Anatolia. Frost reaches up to $90 \mathrm{~cm}$ in this area. The high soil temperatures adversely affecting plant life $\left(35^{\circ} \mathrm{C}\right.$ and above) is seen in the South-East Anatolia Region and Çukurova region in Turkey in July and August. These high temperatures are effective up to $80 \mathrm{~cm}$ in the region. The majority of Turkey has thermic soil or mesic soil. Considering long-term averages (19752018), there are four main soil temperature regimes in Turkey as frigid, thermic, mesic, hyperthermic. The eastern Mediterranean coastline and the southwestern Anatolian coastline are hyperthermic soil temperature regime character and the northeasts Anatolia (Ardahan surroundings) show a frigid temperature regime character. Percentages of thermic and hyperthermic soil temperature regime have been increasing in the last 10 years. The increase is probably due to the above normal average air temperatures from July to December and the breaking of air temperature records in the last 10 years.
\end{abstract}

Keywords: Soil temperature, soil temperature regimes, Soil Taxonomy, Turkey

\section{Introduction}

Determination and mapping of soil temperature regimes are used in soil genesis, soil use, delination tree lines, species distribution modeling and ecological modeling techniques (Natural Resources Conservation Service Soil Survey Staff, 1999; Takata et al., 2011). According to Soil Taxonomy, defining soil temperature regimes allows more precise assessment and interpretation of land use (Takata et al., 2011). In other words, the creation of regime maps is an important step for the soil layer in establishing the land resource inventory. Soil temperature regime maps in current and future land use are an important tool in assessing the land resource and sustainable agricultural production potential (Chiang et al., 2021; Spinoni et al., 2020; Çelik et al., 2019).

Apart from the Soil Taxonomy, the regime of soil temperatures can only be defined by changes in monthly average soil temperatures. The resulting pattern is often shaped by geographic location, latitude, altitude, and terrestriality. Such an analysis is particularly important in terms of agricultural activities, transportation and hydrological factors (such as infiltration and flooding). In this context, defining the soil temperature regime characteristics can make an important contribution to the agricultural climatology of Turkey and National Soil Information System. There are many studies on the soil temperature regime based on both monthly average changes and Soil Taxonomy in the world (Changnon, 1959; Kyuma, 1985; Kaučić, 1989; Mount et al., 1992; Bai, 2009; Takata et al., 2011; Wei et al., 2017; Bradford et al., 2019). Changnon (1959) revealed the average soil temperature character of Urbana-Champaign, Illinois region, USA during the period 1901-1948, and found that the average maximum soil temperature was $20.4{ }^{\circ} \mathrm{C}$ in August and the average minimum soil temperature was $3.8^{\circ} \mathrm{C}$ in February. Kaučić (1989) reported that the soil temperature decreases with depth at $5-20 \mathrm{~cm}$ and 20$30 \mathrm{~cm}$ layers in the Croatian region, but in the second layer, the differences between the terrestrial and coastal regions decrease. It also found that the minimum monthly average soil temperatures were seen in January in all regions, while the maximum monthly average temperatures were seen in July at 5 and $20 \mathrm{~cm}$ depths and in August at $30 \mathrm{~cm}$ depths (in the Adriatic region). Wei et al. (1999) analysed the monthly average soil temperature changes in the Northern Tibetan Plateau of China at 1,10 and $20 \mathrm{~cm}$ soil depths. They found that the highest soil temperatures were seen in July, and the lowest soil temperatures were in January. On the volcanic island Tenerife (Canary Islands, Spain), seven 
of the nine regimes in Soil Taxonomy have been defined: Hyperthermic, thermic, mesic, isohyperthermic, isothermic, isomesic and cryic. A cryic regime has been documented for the first time at this latitude (Rodríguez et al., 2010). According to Takata et al. (2011), who studied the soil temperature regime of Japan, most of the Japanese land is included in the mesic regime, followed by a thermic, frigid and hyperthermic regime. Soil temperatures vary between $3.6-25.8^{\circ} \mathrm{C}$ according to the soil temperature regime model made according to the regression kriging method. The average value is $12.8^{\circ} \mathrm{C}$. Temperatures have higher values in the southern coastal regions than in the northern mountainous regions. Bradford et al. (2019) reported that cryic, frigid, mesic, thermic and hyperthermic regimes are currently observed in western North America. They argued that in dryland systems of western North America the mesic regime will shift north in the near-term and in the long-term, and that the thermic and hyperthermic regimes will expand at the expense of the mesic regime (İmamoğlu and Sertel, 2016; Gorji et al., 2019).

In Turkey, The State Meteorolology Affairs General Directorate (1958) investigated temporal changes in soil temperatures between 1926 and 1955 for 1 site in the Ankara Province of Turkey. In the research, the vertical distribution of temperature showed two cycles as positive and negative during the year, and the negative phase between March-October without considering 0-5 $\mathrm{cm}$; It has been determined that it corresponds to the positive phase between November and February. Acaröz (1960) and Erinç and Bener (1963) spatial and temporal changes in soil temperature in Turkey analysed in a comprehensive manner. They reported that the soil temperatures dropped in September and the temperatures increased towards the west and south. In addition, it has been argued that in January soil temperature change, 0 ${ }^{\circ} \mathrm{C}$ temperature isopleht is found in Eastern Anatolia Region, extending westward to a depth of $15 \mathrm{~cm}$ and retreating to Eastern Anatolia Region at a depth of 30 $\mathrm{cm}$. However, it should be noted that these results were determined with a small number of stations that were not homogeneous in both spatial and temporal scales. Turan (2019) investigated regime types in soil temperature and moisture 10 years and above for 183 meteorological stations in the Eastern Black Sea Section and Central Anatolia Region. According to the Newhall simulation model, it was detected that the soil temperature regime of these regions entered the mesic regime (Sutariya et al., 2021; Röder et al., 2010). Until now, the soil temperature regime of Turkey based on both the Soil Taxonomy and the classical climatic regime approach (monthly average soil temperature change) has not been put forward with a holistic and systematic view. The aim of the study was to define the soil temperature regime types and characteristics of Turkey according to both Soil Taxonomy and classical approach.

\section{Materials and Methods}

Character of soil temperature regime in Turkey was presented with a classical graphical approach and Soil
Taxonomy approach. In the classical approach, 14 stations (Tekirdağ, Aydın, Tefenni, Adana, Giresun, Rize, Ankara, Kayseri, Malatya, Erzincan, Ardahan, Iğdır, Siirt and Şanlıurfa) were used to represent the changes in latitudinal and longitudinal lines at certain intervals. Six of the fourteen stations have a lack of observation in some months, so these months are not included in the graphs. Only $5 \mathrm{~cm}, 10 \mathrm{~cm}$ and $20 \mathrm{~cm}$ data were used at the Iğdır station, and January and February were excluded from the analysis for $10 \mathrm{~cm}$ and $20 \mathrm{~cm}$ data. In addition, there are no data for January-April and November-December in the $50 \mathrm{~cm}$ data of Malatya station in the graphs. At Ardahan station, there is no data on January-March and December at $10 \mathrm{~cm}$ and JanuaryMarch at $20 \mathrm{~cm}$ and February data at $50 \mathrm{~cm}$. The data of January and February at $10 \mathrm{~cm}$ and $20 \mathrm{~cm}$ at the Kayseri station and the data of January, February and December at the Erzincan station are not available due to the lack of data in the graphics. Soil temperature regime changes in vertical profile are defined by contour mapping method. In this context, intermediate values were estimated by Akima's polynomial method (Akima, 1978) for terrestrial regions and distance method for coastal regions.

Turkish soil temperature regime in soil taxonomy approach, it has been defined according to the soil temperature criteria in the Soil Taxonomy (Natural Resources Conservation Service Soil Survey Staff, 2014). In this context, data of 153 meteorology stations were used. Offer a complete description of the experimental design and methods used to acquire these data. Please provide any programs or code files used for filtering and analysing these data. It is very important that this section is as comprehensive as possible.

\section{Results \\ Soil temperature regime according to monthly soil temperature fluctuations}

Although the annual course of soil temperatures can be shown with maps showing monthly averages, it is difficult to follow the values reached by soil temperatures at certain depths at certain times. To analyze the changes in both horizontal and vertical in more detail, the annual course of soil temperature was defined by taking into account 6 profiles, both latitudinal and longitudinal, and 14 stations at certain intervals (Figure 1). According to the Profile-1 results, there are some differences between north and south. The average soil temperature in Tefenni is lower than Tekirdağ at all depths which is influenced by geographic location and terrestriality. The frequent crossing of the curves in the graph, in other words, the increase in the annual temperature difference is a sign of this. In the Tekirdag region, soil temperatures do not fall below $5{ }^{\circ} \mathrm{C}$ which is important in terms of vegetation in winter. Unlike the winter season, the opposite situation is observed in summer, especially in July, August and September. Temperatures above $25^{\circ} \mathrm{C}$ can reach up to $100 \mathrm{~m}$ depth in the Tefenni Plain compared to the Tekirdağ region. 


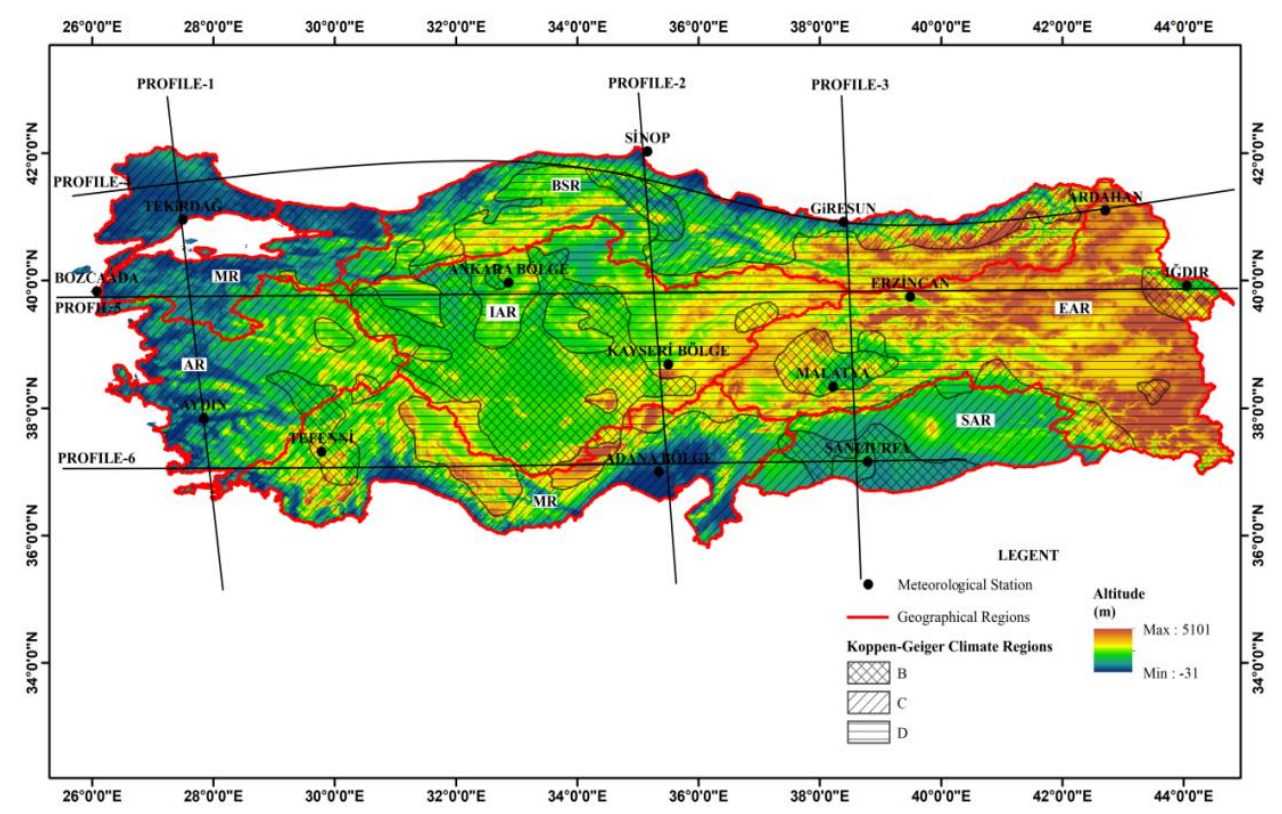

Fig. 1. Location of 14 stations representing the profile lines, the geographical regions and Köppen-Geiger main climate groups. B, C and D represent dry, temperate and continental climates, respectively (Öztürk et al., 2017).

According to the results of Profile-2, it is seen that latitude and terrestrial are effective in monthly changes of soil temperatures. While the annual soil temperature difference (amplitude) is close to each other in the coasts, it is higher in the interior. There are differences between summer and winter soil temperatures in the northernmost (Sinop) and southern coasts (Adana) of Turkey. This is evident in the summer, although the southern shores are warmer than the northern shores. In the summer, soil temperatures of $30{ }^{\circ} \mathrm{C}$ and above in the Adana region can reach up to $78 \mathrm{~cm}$, while soil temperatures of $25{ }^{\circ} \mathrm{C}$ and above in Sinop coasts can reach these depths. Soil temperatures on the coasts do not fall below $5{ }^{\circ} \mathrm{C}$ which is important for vegetation throughout the season. On the contrary, soil temperatures in the inner parts (Kayseri) are below $5{ }^{\circ} \mathrm{C}$ for 5 months of the year (November-March). Even the months of January and February are the frost period. Although there is frost up to $29 \mathrm{~cm}$ on average in January and February, the frost layer thickness can go up to $34 \mathrm{~cm}$ in January when the soil temperatures are the lowest. However, considering that the $0{ }^{\circ} \mathrm{C}$ isotherm of the absolute frost phase expands from the Eastern Anatolia Region to the inner parts of the Central Anatolia Region, it should not be ignored that it is $5 \mathrm{~cm}$ deep in January (Figure 2).

According to the results of Profile-3, the effect of altitude and terrestrial is in the foreground in monthly changes of soil temperatures. It is $4{ }^{\circ} \mathrm{C}$ in the inner parts (Erzincan) while the amplitude value of the shallow soil layers of the coasts is $13{ }^{\circ} \mathrm{C}$ (Giresun). This $9{ }^{\circ} \mathrm{C}$ difference in the shallow soil layers of the coastal and inland areas decreases with depth and decreases to $5{ }^{\circ} \mathrm{C}$ in deep layers. The highest temperatures are shifting from July to August as the depth increases. Soil temperatures are higher in Şanlıurfa station. It is seen that the soil temperatures shifted from July to August after $30 \mathrm{~cm}$ on the Black Sea coast, $20 \mathrm{~cm}$ in inner parts and $70 \mathrm{~cm}$ in Şanliurfa. The continuation of summer temperatures in Şanliurfa up to the deeper layers compared to other areas is due to the fact that the region is weak in terms of vegetation and the combined effect of the Persian Gulf low pressure system which brings very hot and dry air mass in summer. Temperatures in the region exceed $35{ }^{\circ} \mathrm{C}$ in the $11 \mathrm{~cm}$ soil layer in summer (July and August). This can be explained by the summer activity of the system of the Persian Gulf low pressure which essentially controls the climate of the region. In Giresun and Şanlıurfa stations, soil temperatures do not fall below $5{ }^{\circ} \mathrm{C}$. On the contrary, the soil temperatures in the inner parts (Erzincan) are below $5{ }^{\circ} \mathrm{C}$ for 5 months of the year (November-March). Even the months of January and February are the frost period. Although there is frost up to $29 \mathrm{~cm}$ in average in January and February, the frost layer can be reached up to $40 \mathrm{~cm}$ in January when the soil temperatures are the lowest (Figure 2).

According to the results of Profile-4, the effect of longitude, altitude and terrestrials is in the foreground in the monthly change of soil temperatures. Temperatures are high in August and generally decrease from west to east. Soil temperatures are higher in Tekirdağ: The average annual soil temperatures at $5 \mathrm{~cm}$ and $50 \mathrm{~cm}$ are $16.7{ }^{\circ} \mathrm{C}$ and $16.3{ }^{\circ} \mathrm{C}$, respectively. Although the soil temperatures in Sinop are slightly higher than Giresun, they have a similar pattern due to the stabilizing effect of the marine. 

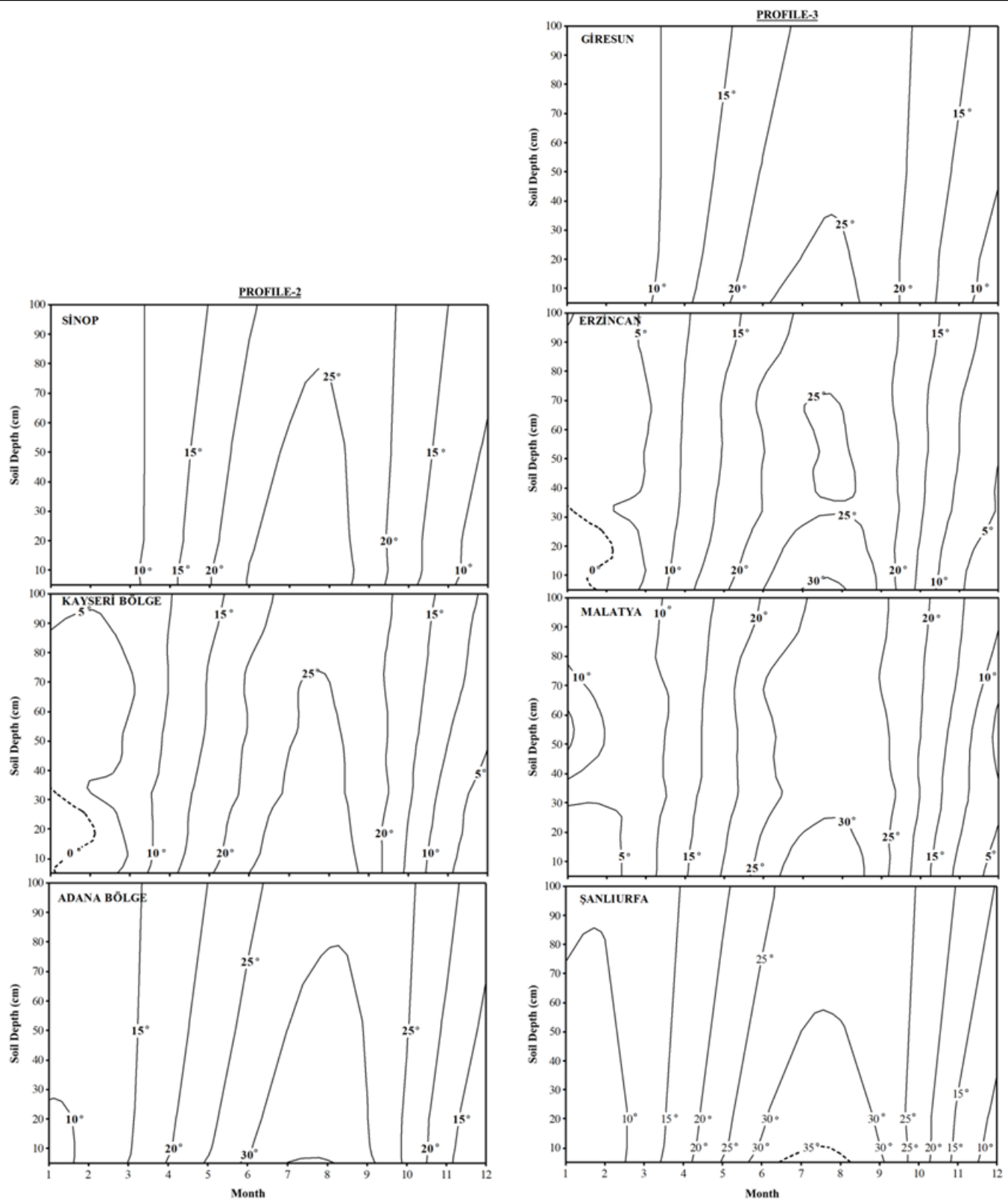

Fig. 2. Fluctuations of monthly average soil temperature at a depth of 5-100 cm on the Profile-2 and Profile-3 line.

The continuation of summer temperatures $\left(\geq 25^{\circ} \mathrm{C}\right)$ in Tekirdağ compared to other areas up to the deep layers is due to the fact that the region is in the MediterraneanBlack Sea transition climate. In Ardahan, soil temperatures drop to $8.0^{\circ} \mathrm{C}$ at a depth of $5 \mathrm{~cm}$ and to 6.7 ${ }^{\circ} \mathrm{C}$ at a depth of $50 \mathrm{~cm}$, with the effect of altitude and continentality. Roughly soil temperatures northeastern Turkey from northern coast is twice as cold. The annual amplitude of the soil temperature at a depth of $5 \mathrm{~cm}$ in the Ardahan region is $16{ }^{\circ} \mathrm{C}$ higher than the northern coasts (Tekirdağ, Sinop and Giresun). This difference disappears when you reach a depth of $50 \mathrm{~cm}$. However, soil temperatures above $20{ }^{\circ} \mathrm{C}$ can be effective up to a depth of $12 \mathrm{~cm}$ in July and August. Moreover, soil temperatures in northeastern Anatolia (Ardahan) are below $5{ }^{\circ} \mathrm{C}$ for 7 months of the year (October-April). Even the November-February period is the frost period. Frost reaches up to $90 \mathrm{~cm}$. In January, February and March, temperatures drop below $-5^{\circ} \mathrm{C}$ up to $30-38 \mathrm{~cm}$.
On the contrary, soil temperatures in Tekirdağ, Sinop and Giresun do not fall below $5{ }^{\circ} \mathrm{C}$ (Figure 3). Altitude and terrestriality are the main factors in the difference of soil temperature change in Ardahan region from northern coasts. However, the presence of relatively stable continental polar air masses that reduce the prevailing winter air temperatures and the relatively unstable marine tropical air masses that increase summer air temperatures should not be ignored.

According to the results of Profile-5, altitude and terrestriality are effective in monthly changes of soil temperatures. Temperatures are high in August and generally decrease from west to east, except for Iğdır Plain. In Iğdır Plain, summer temperatures are $4{ }^{\circ} \mathrm{C}$ higher than Bozcaada. Bozcaada is $3{ }^{\circ} \mathrm{C}$ higher than the inner parts and $2{ }^{\circ} \mathrm{C}$ higher than the Iğdır Plain. Annual average temperature amplitude values are also increasing from west to east. Soil temperature amplitude values at a 
depth of $5 \mathrm{~cm}$ are $20^{\circ} \mathrm{C}, 27^{\circ} \mathrm{C}, 30^{\circ} \mathrm{C}$ and $33^{\circ} \mathrm{C}$ from west to east, respectively. Soil temperatures do not drop below $5{ }^{\circ} \mathrm{C}$ in 7 months (April-October) in Ankara. Although temperatures of $5^{\circ} \mathrm{C}$ and below are seen up to $73 \mathrm{~cm}$ in February, frost line is not seen (Figure 3). As seen in Profile-5, the amplitude in the Iğdır Plain is higher than both the coastal and inland parts. This regional difference can be explained by the dominance of tropical air masses in summer and continental polar
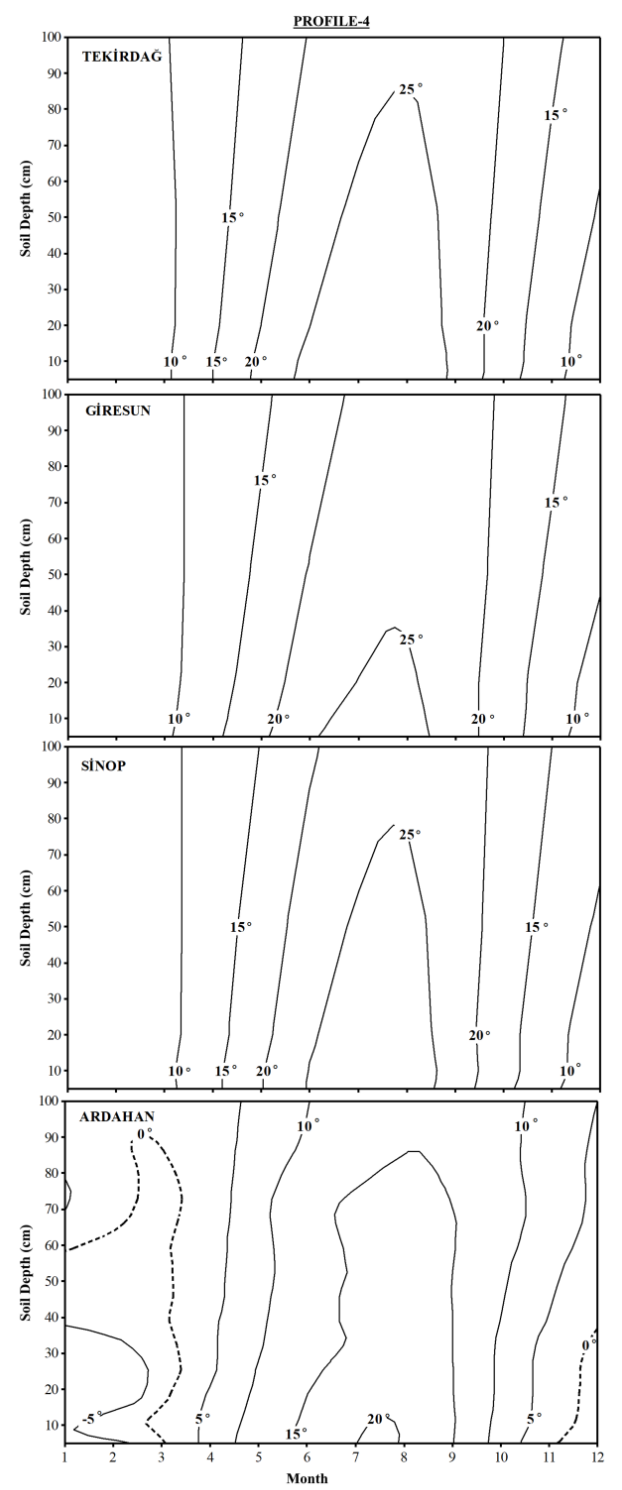

Fig. 3. Fluctuations of monthly average soil temperature at a depth of 5-100 cm on the Profile-4 and Profile-5 line.

According to the results of Profile-6, the effects of terrestrial and longitude appear in monthly changes of soil temperatures. frost conditions in soil layers in this profile line in the southern part of Turkey is not seen. In the Çukurova region (Adana), the annual average temperature amplitude values are approximately $3{ }^{\circ} \mathrm{C}$ lower than in Tefenni and Şanlıurfa. The amplitude values of Adana region are $33^{\circ} \mathrm{C}, 30{ }^{\circ} \mathrm{C}, 30^{\circ} \mathrm{C}, 24^{\circ} \mathrm{C}$. and $20^{\circ} \mathrm{C}$ according to the depths of $5,10,20,50$ and $100 \mathrm{~cm}$, respectively. The low amplitude is due to the marine effect. High temperatures $\left(\geq 30{ }^{\circ} \mathrm{C}\right)$ are dominant in Adana and Şanliurfa. Although these temperatures are penetrated up to $27 \mathrm{~cm}$ in the June-September period, air masses in the plain, except that the plain is surrounded by high mountains. This dynamic structure of the topography and climate which prevents the temperate air masses from reaching the region causes the summer to be very hot and the shallow-depth soil temperatures to be higher than the inner parts. In winter, due to the domination of continental polar air masses and very cold conditions, shallow-depth soil temperatures fall below $0 \quad{ }^{\circ} \mathrm{C}$ and frost line occurs.
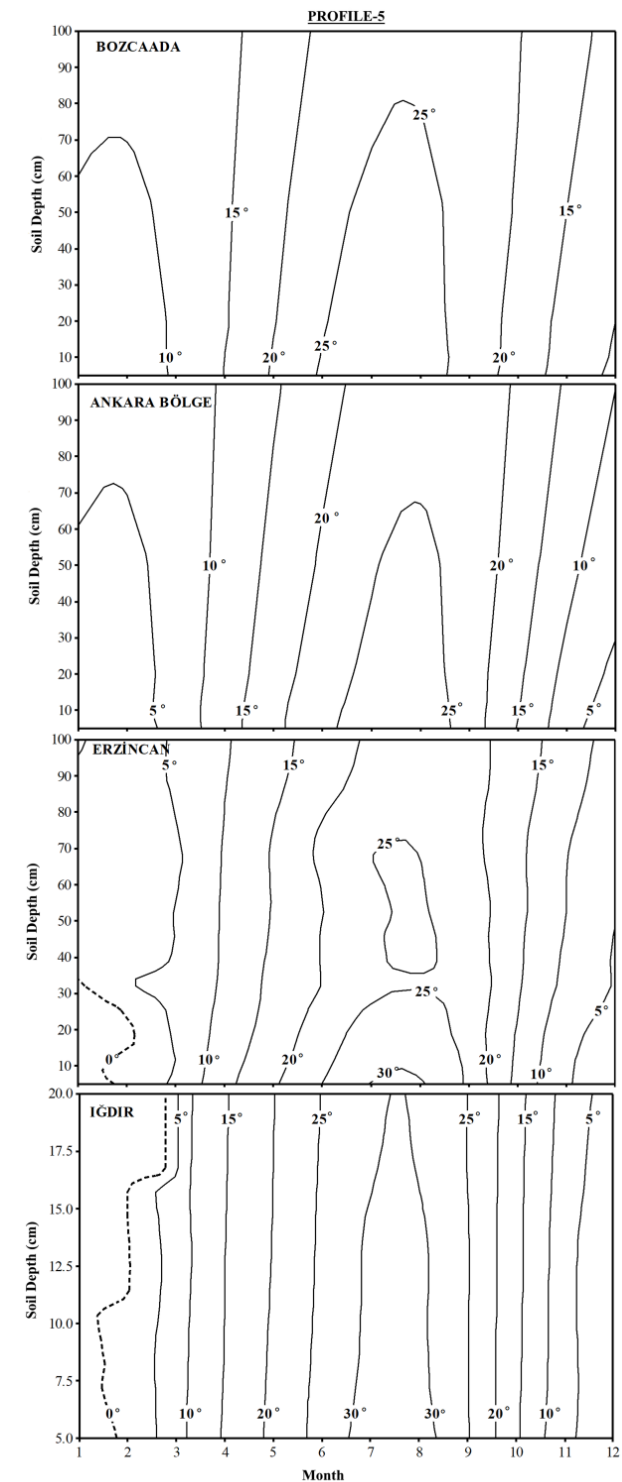

they are effective up to a depth of $70-80 \mathrm{~cm}$ in August and September.

\section{Soil temperature regime according to Soil Taxonomy}

In Turkey, located in the middle latitude (temperate) climate zone and surrounded by the sea on three sides, there are four types of temperature regimes: Frigid, mesic, thermic and hyperthermic. The thermic regime is dominant below 1000 meters in general, especially in the 0-250 m coastal zone. Mesic regime is observed at altitudes above 1000 meters, in other words in the inner parts of Turkey. Apart from these soil temperature regimes in Turkey, frigid and hyperthermic regime types 
are also observed in some areas. The frigid soil temperature regime around Ardahan and Sarıkamış at altitudes above $1800 \mathrm{~m}$ in northeastern Anatolia; Hyperthermic regime is mainly distributed in the Mersin region which is located on the eastern Mediterranean coast. Iğdır Plain soils are warmer than their surroundings and differentiate in terms of entering the type of thermic regime contrary to the mesic regime (Figure 4).

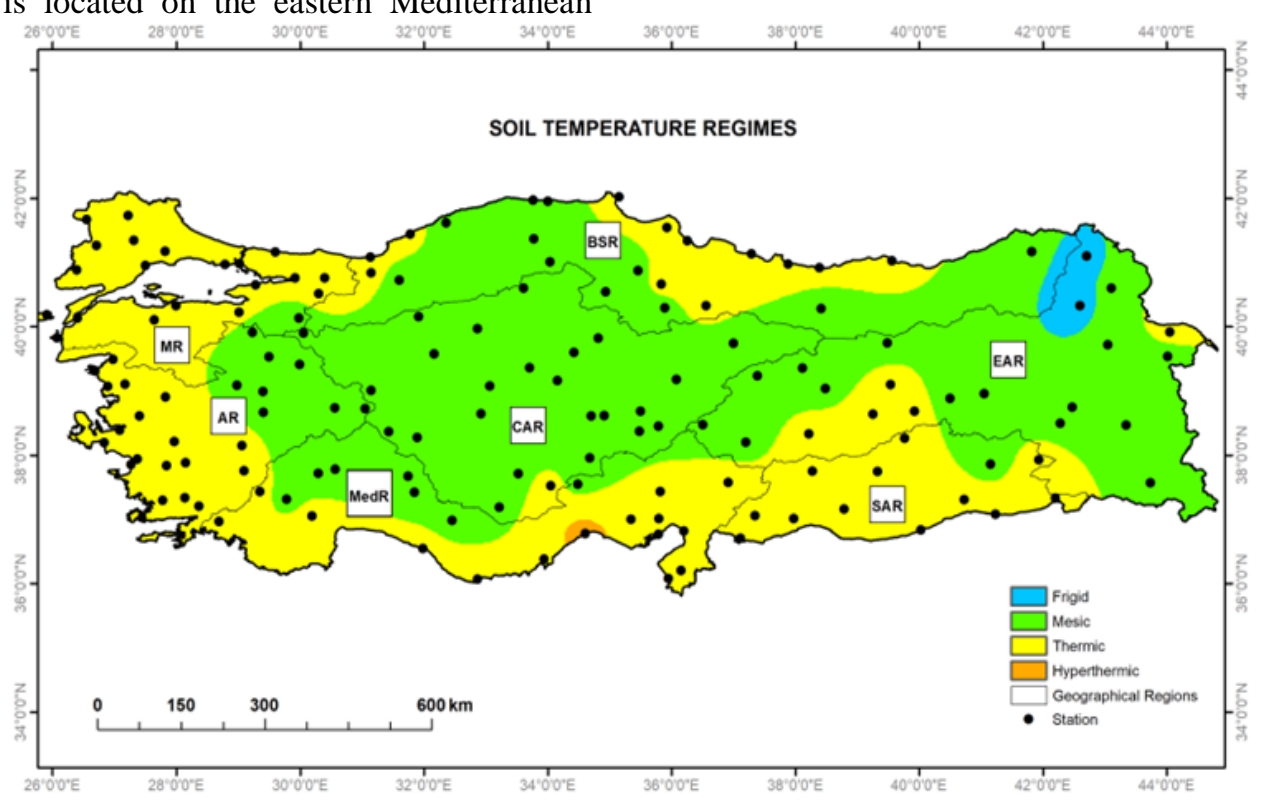

Fig. 4. Turkish soil temperature regime according to Soil Taxonomy. (BSR: Black Sea Region; MR: Marmara Region; MedR: Mediterranean Region; CAR: Central Anatolia Region; EAR: Eastern Anatolia Region; SAR: Southeastern Anatolia Region).

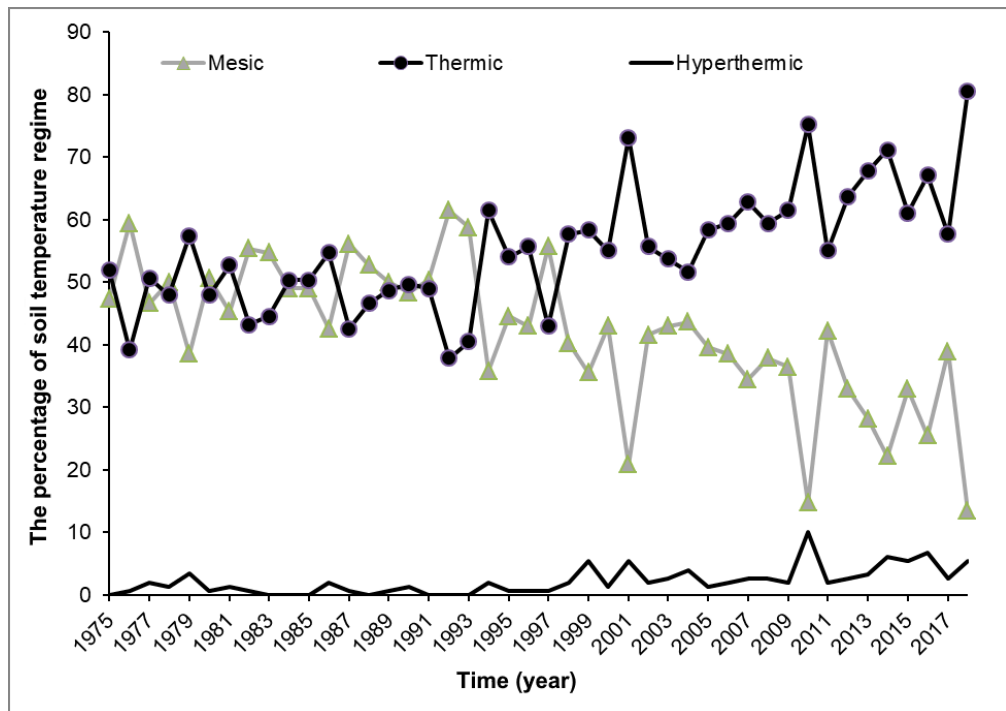

Fig. 5. Temporal variations of three different soil temperature regime defined in Turkey (hyperthermic and pergelic soil temperature regime percentages are not included in the graph because they were too low).

The temporal variations of mesic soil are are opposite to those of thermic and hyperthermic. The coldest 2018 year had the lowest percentage of thermic soil of $13.42 \%$ while the hottest year 1992 has the highest percentage of thermic soil of $61.49 \%$ (Figure 5). The majority of the Turkey region has either the thermic soil or mesic soil. These two types together account for $89.93 \%$ of the region in 2010 to $99.33 \%$ in 1991 . The percentage of thermic soil varies from $34.84 \%$ in 1992 to $80.54 \%$ in 2018. The percentage of hyperthermic soil varies from $0.00 \%$ in 1975 to $10.07 \%$ in 2010 . The temporal variations of frigid and pergelic soil are opposite to each other. The percentage of frigid soil varies from $0.68 \%$ in 1975 to $0.00 \%$ in 2018 . The percentage of pergelic soil varies from $0.00 \%$ in 1975 to $0.68 \%$ in 1992 and 1993 .
To analyze the detailed temporal changes, the temporal distribution of the soil temperature regime was examined by dividing the data into nine groups: 1975-1979, 19801984, 1985-1989, 1990-1994, 1995-1999, 2000-2004, 2005-2009, 2010-2014 and 2015-2018. Table 1 summarizes the percentage of each regime for these nine periods.

The mesic soil percentage decreases from $48.38 \%$ to $27.68 \%$ while the percentage of thermic soil increased from $49.46 \%$ in the period of $1975-1979$ to $66.61 \%$ in the period of 2015-2018. The hyperthermic soil percentage trend is consistent with the hyperthermic percentage and increases from $1.49 \%$ in the $1975-1979$ periods to $5.03 \%$ in the $2015-2018$ period. The 
consistency in this trend is also evident in the pergelic soil temperature regime percentage (Table 1). Both thermic and mesic soils constitute approximately $99 \%$ of the region in the 1980-1994 periods and this percentage is higher than the other six periods. In the period of 2014-2018, thermic and mesic soils constitute $94.30 \%$ of the region and this percentage is lower than the other eight periods. The percentage of both thermic and hyperthermic soils increased from $50.95 \%$ in the period $1975-1979$ to over $71 \%$ in the period $2010-2018$, which showed that the 2010-2018 period was significantly hotter than the other seven periods.

Table 1. Percentage of each soil temperature regime based on a five-year period.

\begin{tabular}{cccccc}
\hline Year & Pergelic $(\%)$ & Frigid $(\%)$ & Mesic $(\%)$ & Thermic $(\%)$ & Hyperthermic $(\%)$ \\
\hline $1975-1979$ & 0.00 & 0.68 & 48.38 & 49.46 & 1.49 \\
$1980-1984$ & 0.27 & 0.41 & 51.01 & 47.77 & 0.54 \\
$1985-1989$ & 0.00 & 0.67 & 50.07 & 48.58 & 0.68 \\
$1990-1994$ & 0.40 & 0.27 & 50.95 & 47.70 & 0.67 \\
$1995-1999$ & 0.00 & 0.54 & 43.82 & 53.76 & 1.89 \\
$2000-2004$ & 0.40 & 0.27 & 38.39 & 57.85 & 3.09 \\
$2005-2009$ & 0.13 & 0.00 & 37.38 & 60.33 & 2.16 \\
$2010-2014$ & 0.40 & 0.13 & 28.05 & 66.58 & 4.83 \\
$2015-2018$ & 0.67 & 0.00 & 27.68 & 66.61 & 5.03 \\
\hline
\end{tabular}

\section{Discussion}

Soil temperature varied between the coastal and inland parts of Turkey and the western and eastern half. Similarly Erinç and Bener (1963) argued that significant differences between the coastal and inland regions in Turkish soil temperature regime. Latitude and continentality shaped the soil temperature regime in the eastern half of Turkey while elevation shapes the soil temperature regime in the western half of Turkey. The frost was seen in the eastern half of Turkey in January and February, except for coastal areas. Morever, the frost period went up to four months (November-February) in northeastern Anatolia.

According to the depth of the $0{ }^{\circ} \mathrm{C}$ isotherm, frost was seen in the eastern half of Turkey in January and February, except for coastal areas. Morever, the frost period went up to four months (November-February) in northeastern Anatolia. The frost reached up to $90 \mathrm{~cm}$ in this area. The high soil temperatures adversely affecting plant life $\left(35^{\circ} \mathrm{C}\right.$ and above) was seen in the South-East Anatolia Region and Çukurova region in Turkey in July and August. These high temperatures were effective up to $80 \mathrm{~cm}$ in the region.

The majority of land in Turkey has thermic soil or mesic soil. Considering long-term averages (1975-2018), there are four main soil temperature regimes in Turkey as frigid, thermic, mesic, hyperthermic. However, due to the climatic variability of the last 10 years, hyperthermic and cryic soil temperature regimes is observed in the eastern and southwestern Mediterranean coastlines and around Ardahan, respectively. Pergelic soil temperature regime observed in permafrost regions has not been observed in any time period in Turkey. The reason for the increase in thermic and hyperthermic soil temperature regime percentages in the last 10 years is probably the average air temperatures above normal from July to December and breaking of air temperature records, increase of extremely hot days and maximum air temperatures (Çelik and Özalp, 2011; Erlat and
Türkeş, 2015, Acar, Gönençgil and Gümüşoğlu, 2018; Türkeş and Erlat, 2018).

The soil temperature regime pattern in the Turkey is similar to that of the Croatia, namely, in both regions, soils in areas of maritime and continental effect fall under the category of thermic and mesic regime respectively (Husnjak et al., 2014). The soil temperature regime of Turkey also has similar characteristics with Japan in terms of latitudinal distribution (Kyuma, 1985; Takata et al., 2011). The most dominant soil temperature regime type in Japan like Turkey, is also mesic. Soil temperature regime in Japan from south to north like Turkey varies among hyperthermic, thermic, mesic and frigid. The soil temperature regime of Okinawa Island which is $10^{\circ}$ further south than Japan, and the soil temperature regime type of Ardahan and Sarıkamış and Hokkaido Island located $1{ }^{\circ}$ further south are similar (Kyuma, 1985; Takata et al., 2011).

\section{Conclusion}

Turkish soil temperature regime is defined by both the latitudinal and longitudinal profiles. This characterization was made with contour plots based on six profiles and fourteen stations. Moreover, the Turkish soil temperature regime based on Soil Taxonomy was revealed with 153 station data.

The most important feature that draws attention in the soil temperature regime of Turkey is the observation of a pronounced decrease in soil temperatures in September. So, at a depth of $5 \mathrm{~cm}$, soil temperatures decrease by 5 ${ }^{\circ} \mathrm{C}$ compared to the previous month. The maximum soil temperature shifts from July to August after $30 \mathrm{~cm}$ in the northern coastline, after $20 \mathrm{~cm}$ in the central and $70 \mathrm{~cm}$ in the southern coastline Turkey. The temperature fluctuations in January show that the frost phase expands from the Eastern Anatolia Region to the inner parts of the Central Anatolia Region at a depth of $5 \mathrm{~cm}$. especially in northeastern Anatolia, frost depth can reach up to $90 \mathrm{~cm}$ in the November-February. Maximum soil 
temperatures, i.e., temperatures above $35{ }^{\circ} \mathrm{C}$, are effective only in the soils of the Southeastern Anatolia Region to depths of more than $10 \mathrm{~cm}$ in July and August. Temperatures above $30{ }^{\circ} \mathrm{C}$ penetrate up to approximately $80 \mathrm{~cm}$ in the south coast of Turkey and the Southeastern Anatolia Region in summer. "Hot spots" of soil temperature changes are identified in the Southeastern Anatolian Region and the Çukurova region of Turkey.

The spatial distribution of soil temperature regimes in Turkey is mainly shaped by altitude and terrestrialmaritime. There are four types of temperature regimes: Frigid, mesic, thermic and hyperthermic. Most of the land is characterized by mesic and thermic regimes. Locally, frigid soil temperature regime around Ardahan and Sarıkamış at altitudes above $1800 \mathrm{~m}$ in northeastern Anatolia; Hyperthermic regime in Mersin region is dominant. However, incidence of thermic and hyperthermic regimes in many regions has increased since 1992 at the expense of the mesic regime.

In conclusion, this study benefits both Turkish agricultural climate science and phenology studies. The results provide new and up-to-date information to the Turkish land inventory. The maps, plots and spatial information we have reached can be evaluated as collective planning information and can be used in the National Soil Information System.

\section{Acknowledgements}

This research was produced from İlyas Sadik TEKKANAT's doctoral thesis titled "Changing in Soil Temperatures in Turkey" conducted under the supervision of Beyhan ÖZTÜRK. We thank the Turkish State Meteorological Service for providing daily soil and air temperature data.

\section{References}

Acar, Z., Gönencgil, B., Gümüşoğlu, N. K. (2018). Long-term changes in hot and cold extremes in Turkey. Journal of Geography, 37, 57-67 (in Turkish).

Acaröz, E. (1960). Türkiye'de Toprakaltı Suhuneti (Soil temperatures in Turkey) (Unpublished thesis). İstanbul Üniversitesi Istanbul University, Istanbul, Turkey (in Turkish).

Akima, H. (1978). A method of bivariate interpolation and smooth surface fitting for irregularly distributed data points. ACM Transactions on Mathematical Software (TOMS), 4 (2), 148-159.

Bai, Y. (2009). Distribution of soil temperature regimes and climate change in the Mojave Desert Region (Unpublished Ph.D. thesis), University of California Riverside, California, USA.

Bradford, J. B., Schlaepfer, D. R., Lauenroth, W. K., Palmquist, K. A., Chambers, J. C., Maestas, J. D., et al. (2019). Climate-driven shifts in soil temperature and moisture regimes suggest opportunities to enhance assessments of dryland resilience and resistance. Frontiers in Ecology and Evolution, 7, 358.
Çelik, S., Özalp, Y. (2011) Assesment of the Heat Waves on the Western on the Western Part of Turkey between 1965 and 2006,. 5th Atmospheric Science Symposium, 27-29 June 2011, İstanbul Technical Üniversity, İstanbul (in Turkish).

Changnon, S. A. (1959). Summary of Weather Conditions at Champaign-Urbana, Illinois. Bulletin 47, Illinois State Water Survey, Urbana.

Chiang, F., Mazdiyasni, O., AghaKouchak (2021). A. Evidence of anthropogenic impacts on global drought frequency, duration, and intensity. Nat Commun, 12, 2754, doi.10.1038/s41467-021-22314-w.

Celik, B., Kaya, Ş., Alganci, U., Seker, DZ. (2019). Assessment of the relationship between land use/cover changes and land surface temperatures: a case study of thermal remote sensing, FEB Fresenius Environ. Bull.,3, 541

Erinç, S., Bener, M. (1963). Soil temperatures in Turkey. İstanbul Üniversitesi Coğrafya Enstitüsü Dergisi, 7 (13), 14-35 (in Turkish).

Erlat, E., Türkeş, M. (2015). Observed changes in the frequencies of record maximum and record minimum air temperatures in Turkey during the period 19502014 and their connections with atmospheric conditions. Aegean Geographical Journal, 24 (2), 29-55 (in Turkish).

Gorji, T., Yıldırım, A., Sertel, E., Tanık, A. (2019). Remote sensing approaches and mapping methods for monitoring soil salinity under different climate regimes. International Journal of Environment and Geoinformatics, 6(1), 33-49, doi.10.30897 /ijegeo.500452.

Husnjak, S., Mesarić, M., Mesić, M. (2014). Determination of soil temperature regimes in Croatia. Agriculturae Conspectus Scientificus, 79 (3), 139143.

İmamoğlu, M. Z., Sertel, E. (2016). Analysis of Different Interpolation Methods for Soil Moisture Mapping Using Field Measurements and Remotely Sensed Data, International Journal of Environment and Geoinformatics, 3(3), 11-25, doi.10.30897 /ijegeo.306477.

Kaučić, D. (1989). Karakteristike temperatura tla u Hrvatskoj. Hrvatski meteorološki časopis, 24 (24), 65-71.

Kyuma, K. (1985). Soil temperature regime of Japanese soils. Soil Science and Plant Nutrition, 31 (3), 463468.

Mount, H. R., Bauer, R. F., Waltman, W. J., Dubee, B. C. (1992). Soil Climate Regimes on the Commonwealth of Puerto Rico and the United States Virgin Islands. USDA-SCS, Soil Survey Division National Soil Survey Center, Lincoln.

Natural Resources Conservation Service Soil Survey Staff (1999). Keys to Soil Taxonomy. U.S. Dept. of Agriculture, Natural Resources Conservation Service, Washington, D.C.

Natural Resources Conservation Service Soil Survey Staff (2014). Keys to Soil Taxonomy. U.S. Dept. of Agriculture, Natural Resources Conservation Service, Washington, D.C.

Röder. A., M. Hubert. S., Stellmes. M., Scarth. P., Bautista. S., Cortina, J. (2010). Characterizing Land 
Use Change in a Complex Semi-arid Landscape by Combined Assessment of Land Transformations and Modifications, Remote Sensing for Science, Education, and Natural and Cultural Heritage, EARSeL, 1-8.

Rodríguez, M., Neris, J., Tejedor, M., Jiménez, C. (2010). Soil temperature regimes from different latitudes on a subtropical island (Tenerife, Spain). Soil Science Society of America Journal, 74 (5), 1662-1669.

Spinoni, J., Barbosa, P., Bucchignani, E., Cassano, J., Cavazos, T., Christensen, J. H., et al. (2020). Future global meteorological drought hot spots: a study based on CORDEX data. J. Clim. 33, 3635-3661. doi: 10.1175/JCLI-D-19-0084.1

State Meteorolology Affairs General Directorate (1958). Thermal Change Laws of Ankara Soils, Ankara (in Turkish).

Sutariya, S., Hirapara, A., Meherbanali, M., Tiwari, M., Singh, V., Kalubarme, M. (2021). Soil Moisture Estimation using Sentinel-1 SAR Data and Land Surface Temperature in Panchmahal District, Gujarat State. International Journal of Environment and Geoinformatics, 8(1), 65-77, doi. 10.30897/ijegeo. 777434.

Takata, Y., Kuwagata, T., Kohyama, K., Obara, H. (2011). Delineation of Japanese soil temperature regime map. Soil Science and Plant Nutrition, 57 (2), 294-302.

Turan, M. (2019). Determination and comparison of soil moisture and temperature regimes of Central Anatolia and East Black Sea regions using Newhall simulation (Unpublished MSc. thesis), Ondokuz Mayıs University, Samsun, Turkey (in Turkish).

Türkeş, M., Erlat, E. (2018). Variability and trends in record air temperature events of Turkey and their associations with atmospheric oscillations and anomalous circulation patterns. International Journal of Climatology, 38 (14), 5182-5204.

Wei, Q., Yili, Z., Linshan, L., Zhaofeng, W., Mingjun, D., Zhilon, Z. (2017). Characteristics of soil temperature variation in core region of Northern Tibetan Plateau in China during 2013-2014. Gegraphical Research, 36 (11), 2075-2087 (in Chinese). 